\title{
Preface to the Special Issue on Geodynamic and Climate-Change Processes over Tibet, Xinjiang and Siberia
}

\author{
Cheinway Hwang, Benjamin Fong Chao, Jeffrey T. Freymueller, Wenbin Shen, and C. K. Shum
}

Citation: Hwang, C., B. F. Chao, J. T. Freymueller, W. Shen, and C. K. Shum, 2011: Preface to the special issue on geodynamic and climate-change processes over Tibet, Xinjiang and Siberia. Terr. Atmos. Ocean. Sci., 22, I, doi: 10.3319/TAO.2010.12.01.01(TibXS)

Tibet, Xinjiang and Siberia (TibXS) are regions with active plate tectonics. Evidence from satellite gravimetry and altimetry shows the hydrological evolutions over these regions are sensitive to global climate change. For example, inter-annual lake level changes over Tibet and Xinjiang from satellite altimetry are found to be connected to the El Niño Southern Oscillation (ENSO). Lakes in central Asia, Xinjiang and Siberia show sharp changes in lake levels that can be explained by climate change. Recent terrestrial gravity, GRACE and GPS observations suggest that the crust over the Tibetan plateau is thickening, and the Himalayan glaciers appear to be thinning. Satellite altimetry is a potential tool to study vertical displacement and permafrost thawing and changes in the active layers in Siberia and Tibet.

This special issue includes some of the distinguished papers presented in the "International Workshop on Gravity, GPS and Satellite Altimetry Observations of Tibet, Xinjiang and Siberia (TibXS)," held on 20 - 22 August 2009 in Urumqi, Xinjiang, China (http://space.cv.nctu.edu.tw/altimetryworkshop/TibXS2009/TibXS2009.htm). This special issue covers the following subjects over TibXS: (1) GPS observations and interpretations; (2) land and satellite-based gravimetry; (3) satellite altimetry observations over lake and land; and (4) data processing techniques for GPS, gravimetry and altimetry. This is the first such issue in an earth science journal dealing exclusively with observations based on GPS, gravimetry and satellite altimetry over TibXS. These papers will promote the advancement of geodynamics, climate and hydrology studies here.

We are grateful to the assistance of the TAO office during the editing and review process. Special thanks go to the responsible editor Dr. Chia Chou, and Miss Mei-Ling Chen. The comments from the reviewers have significantly improved the quality of all papers.

\author{
Responsible Editor: \\ Chia Chou \\ Research Center for Environmental Changes, Academia Si- \\ nica, Taipei, Taiwan, ROC \\ E-mail: chiachou@rcec.sinica.edu.tw
}

\section{Guest Editor:}

Benjamin Fong Chao

Institute of Earth Sciences, Academia Sinica, Taipei, Taiwan, ROC

E-mail: bfchao@earth.sinica.edu.tw

Jeffrey T. Freymueller

Geophysical Institute, University of Alaska, Fairbanks, USA

E-mail: jeff.freymueller@gi.alaska.edu

Wenbin Shen

Department of Geophysics, School of Geodesy and Geomatics, Wuhan University, Wuhan, China

E-mail:wbshen@sgg.whu.edu.cn

C. K. Shum

Division of Geodetic Science, School of Earth Sciences, The Ohio State University, Ohio, USA

E-mail: ckshum@osu.edu

\section{Executive Guest Editor:}

Cheinway Hwang

Department of Civil Engineering, National Chiao Tung University, Hsinchu, Taiwan, ROC

E-mail: cheinway@mail.nctu.edu.tw 